\title{
The Many Faces of Indonesia: Knowledge Production and Power Relations
}

\author{
Hanneman Samuel ${ }^{1} \&$ Oki Rahadianto Sutopo ${ }^{2}$ \\ ${ }^{1}$ Department of Sociology, Faculty of Social and Political Sciences, University of Indonesia, Depok, Indonesia \\ ${ }^{2}$ Department of Sociology, Faculty of Social and Political Sciences, Gadjah Mada University, Yogyakarta, \\ Indonesia \\ Correspondence: Hanneman Samuel, Department of Sociology, Faculty of Social and Political Sciences, \\ University of Indonesia, Depok 16424, Indonesia. Tel: 62-8-1678-4280. E-mail: hanneman.samuel09@ui.ac.id
}

Received: July 9, 2013 Accepted: August 12, 2013 Online Published: September 29, 2013

doi:10.5539/ass.v9n13p289

URL: http://dx.doi.org/10.5539/ass.v9n13p289

\begin{abstract}
Conceptualizations of modern Indonesia were active agents in shaping the way we saw the present Indonesia and its problems. This study is concerned with some major conceptions of modern Indonesia, namely, the primordial sentiments thesis, the transitional stage thesis, the historical structural thesis, and the cultural imperialism thesis. Our specific interest was on comparing the way they treated the Indonesian state and society. It is our argument that involvement of scientific knowledge in the formation of modern Indonesia had been a complex process: scientific knowledge intertwined with common sense in power relations. This had meant Indonesian societies and identities could never be considered to have been monolithic.
\end{abstract}

Keywords: knowledge, power, modernization, developmentalism, postcolonial, Indonesia

\section{Introduction}

This paper is an attempt to examine four sociological concepts of modern Indonesia, namely, the primordial sentiments thesis, the transitional stage thesis, the historical structural thesis, and the cultural imperialism thesis produced since the mid of 1960s. Although most of the mainstream concepts were different from one another, they had been created on the same grand narratives, that is, the modernization perspective. Modern Indonesia had never been naturally developed. Social analysis and political engineering had been observable in organizing Indonesia and the identities of Indonesians. Whether we like it or not, it was Western European and North American intellectuals that had helped create modern Indonesia - on the idea of the state as a survival unit.

The $21^{\text {st }}$ century, however, had changed the map of scientific knowledge, established since the $17^{\text {th }}$ century. Various postcolonial ideas had challenged modernization theories, and this had opened up new venues to understand and change Indonesia. Unfortunately, oppositions to postcolonial thesis of Indonesia remained strong. As a matter of fact, the majority of Indonesian intellectuals need to familiarize themselves with the thesis. It is the aim of this paper to offer an alternative explanation about the conception of modern Indonesia that became taken for granted in the academic discourse. Our position is clear: knowledge is not neutral, knowledge is always related to power and knowledge as both a means of communications and also a means of orientation (Samuel, 2010). It is our aim to deconstruct the linkage between the knowledge production of four theses of modern Indonesia and its relation to power.

\subsection{Relevant Previous Studies about Knowledge and Power Relations in Indonesia}

There are few previous studies about the knowledge production especially sociology and its relation to power in Indonesia specifically made by Indonesian scholars. Four of them deserve mention in this article, they are The Development of Sociology in Indonesia: The Production of Knowledge, State Formation and Economic Change (Samuel, 2001), Cendekiawan dan Kekuasaan dalam Negara Orde Baru (Intelectuals and Power in The New Order State) (Dhakidae, 2003), Social Science and Power in Indonesia (Hadiz \& Dhakidae, 2005) and Negara, Universitas dan Banalitas Intelektual: Sebuah Refleksi dari Dalam (State, University \& Banality of Intelectuals: an Insider's Reflection) (Nugroho, 2012).

Samuel (2001) examined the production of Indonesian sociology from the Dutch era until the era of the New Order, eclectically using perspective from Foucault, Elias and Said. One of his contributions is how he described 
the shift of the knowledge producer of Indonesian sociology from the Indologist to the Indonesianist, it also reflected the shift of dominant power from Dutch to American. As pointed out by Connell (2007), it shows the phenomenon of grand erasure resulted from the unequal power relation between Metropole and Periphery. While Dhakidae (2003) and Hadiz and Dhakidae (2005) explained the relation between power especially represented by the state (New Order Regime) and the production of social science in Indonesia. Nugroho (2012) further expanded the argument into the case of the intellectual in one of the biggest universities in Indonesia, his original contribution is how he described the tendency of banality among intellectuals in the era of market domination in Indonesia. Four previous studies had given precious contributions in Indonesian sociology, but none of them specifically examined knowledge production of four theses of modern Indonesia and its relation to power, we would like to bridge the gap and this became the original contribution of our paper.

\subsection{The Context of Knowledge Production in the Era of New Order in Indonesia: A Brief Narrative}

The process of knowledge production, especially in sociology within Indonesia could not be separated from the context of post World War II and its impact both internally and globally. Internally, Indonesia experienced the shift of power from Old Order/Orde Lama (1945-1965) to New Order/Orde Baru (1966-1998) while globally after independence from the Dutch, Indonesia was in the middle of contestation between USA influence (capitalist oriented) and USSR influence (socialist oriented). Objectively, Indonesia was more oriented to the influence of USA (Sutopo, 2012a). Two historical facts can be significant moments to show the shift of power, especially during the period of Indonesian proclamation of independence from the Dutch (1945-1949) and also between 1965 - 1966 when the military coup supported by USA intelligence succeeded to marginalize the leftist (Simpson, 2008; Rossa, 2008). Briefly after the 1965-1966 coup, in terms of economic production Indonesia was more open to global economy/investment, development agenda based on capital accumulation and modernization of culture (Sutopo, 2012a).

As explained by Samuel (2001), sociology in Indonesia experienced a shift of power from indologist to indonesianist or from domination of Dutch scholars to American scholars. To explained briefly, in the colonial era the indologists constructed knowledge which positioned the colonized below their colonizer and gathered data beneficial to forming policy to strengthen colonial domination. One great explanation was made by Alatas (1977) about The Myth of the Lazy Native.

In the era of the New Order, slowly the influences of Dutch scholars were replaced by U.S. dominant Post World War II sociology. In terms of discourse, it also meant that the colours of Indonesian sociology were dominated by the influences of American Sociology. As a means of communication and orientation, the types of knowledge were produced to support the agenda of development and modernization under the hegemony of USA as the victor of World War II. As explained by Connell (2010):

During the cold war, the US state and corporate leadership tried to implant western social science in developing countries. Students were brought to US universities, departments were funded and research grants provided in their home countries. For a time, the Ford Foundation and Rockefeller Foundation became the largest financial supporter for social science research.

Furthermore, it was the first generation of Indonesian sociologists who took their $\mathrm{PhD}$ in Sociology from the first class American Universities who brought the influences to education curricula and objectively through the first sociology text books titled Setangkai Bunga Sosiologi (Soemardjan \& Soemardi, 1964). As explained by Samuel (2001), the first generation of sociologists worked simultaneously as bureaucrats who served the state and also as social scientists who believe in objectivity and value free. This ambiguous position has an impact on the construction of sociological knowledge especially to support the agenda of national stability and also the process of development and modernization maintained by New Order regimes. Further, the state also had used its authority to control and construct the curricula of higher education so it would adhere to the agenda of New Order regimes (Nugroho, 2005). At the other side, the state also controlled the sociological association, it was easy to acknowledge that sociological association was no more than a representation of the state (Laksono, 2005).

Despite the total hegemony of the state, there were always alternative voices in the construction of sociological knowledge in Indonesia but only outside the campus, especially discourse that was built by Non-government organization (NGO). This was not last longer, according to Ganie-Rochman and Achwan (2005) the alternative discourse was easily absorbed into the agenda of development and modernization by New Order regime.

It was not until late in the New Order era and post reformation era when Frankfurt school, Cultural Studies, Postmodern theory, Postcolonial Theory were exported to sociology curricula and taught in the university. It shows a positive aspect especially how the education climate is more open after the reformation era (Note 1). 
Despite all these positive facts, as second author observations during the national sociological conference in Malang, East Java Indonesia (2012) the majority of university and scholars in Indonesia still have a strong orientation towards development and modernization perspectives.

\section{The Primordial Sentiment Thesis}

Scholarly attempt to perceive Indonesia as a pluralistic society is traceable to J. S. Furnivall's analysis of East Indies (Vickers, 2004). To him, unlike in the West, East Indies represented a society bound together by colonial power rather than by common will. People in East Indies organized themselves according to cultural units, and the units were autonomous vis-à-vis each other with reference to institutional arrangement. An ethnic group was able to maintain its existence without the support of the other. Inter-ethnic relations, accordingly, were confined to economic transactions, between buyers and sellers.

The social systems had existed long before the arrival of the Dutch as a colonizer. The Dutch themselves had legally strengthened the pluralistic character of East Indies, that is, by sanctioning different sets of law for Europeans, Chinese and other Far Eastern people, and indigenous people. To Wertheim (1969), this had reinforced race stratifications.

Another authoritative figure on conceiving Indonesia as a mosaic of primordial ties was Clifford Geertz. He did numerous studies on Indonesia particularly from the 1950s to the 1970s and used the concept "primordial attachment" to refer to assumed blood ties, race differences, language differences, regions, religions, and customs. By a primordial attachment itself was:

Meant one that stems from the "givens" -- or, more precisely, as culture is inevitably involved in such matters, the assumed "givens" -- of social existence: immediate contiguity and kin connection mainly, but beyond them the givenness that stems from being born into a particular religious community, speaking a particular language, or even a dialect of a language, and following particular social practices (Geertz, 1973).

What was the sociological significance of studying primordial ties for Indonesia? Proponents of pluralistic society thesis had a tendency to associate primordial sentiments with nation building. The explanation had run as following: (1) As Indonesia was a young State, nationalism was particularly inevitable. (2) Unfortunately primordial loyalties were not automatically vanished along with the proclamation of Indonesia's independence in 1945. (3) It was highly relevant to conduct scientific studies on the extent to which communal tensions and conflicts had upset the project of nation building. (4) The use of rigorous scientific methodology was sufficient condition for preparing studies on, amongst others, social distance, ethnic relations, the politics of Islam, and ethnic response to everyday life problems.

Local influential scholars had also joined the choir and, mutual reference between the two had been strengthened by the state. The New Order had formulated policies to retain boundaries among ethnic groups, races, religious groups, and ideological groups. As such, State terrorism was considered inevitable and had often been associated with political propagation of the so called "social harmony" (Heryanto, 2006). Each cultural group had also been intervened in order to make it compatible with and supportive to economic development. Through, amongst others, the Media and education, the state had always made Indonesians aware of the cultural groupings they belong to. Chinese Indonesians had also been made aware of their vulnerabilities through discriminative policies. Muslims were the same. From time to time, Islamic communities experienced intervention.

What was its political impact? As the idea of Indonesia as a pluralistic society had been closely associated with threats of communal tensions, the importance of inter-groups management had found its relevance throughout the New Order era. It had also been used by the state to justify its role to supervise and control inter-group relations. On a broader scale, this had also provided scientific justification for state intervention in religious and cultural life at large. It was within this context, amongst others, that the New Order's opposition against the implementation of Human Rights was to be understood.

The intervention itself had been conducted through bureaucratic mechanisms, organized in an authoritarian style. Ideological, legal, and coercive measurements had been utilized. This, furthermore, had gone hand in hand with the state's domination over the discourse of National Integration and its National Development scheme. Unfortunately, adequate research findings were yet to be produced - if at all - whether the interventions had been primarily optional or compulsory. At present, it was suffice to say that scientific methodology and political power had been used for fabricating the pluralistic feature of Indonesia and to ensure effective regime maintenance (Samuel, 2001).

Impacts of fabricating essentialist view of primordial sentiments had gone beyond the New Order era. The New Order inclination towards division of Indonesia into cultural groups had been taken over voluntarily by 
Indonesians to reproduce political identities. The reformation era had seen the development of religious organizations and political parties, vigilantes, and ethnic based organizations. Nativistic views of the Putera Daerah, and, to a lesser degree, separatist movements in several places in Indonesia for example Papua, Aceh and Moluccas had also arisen. At the other side, the politicization of local identities resulted on the creation of new raja-raja lokal (local leaders) who abused their power to hijack the democratic process (Hadiz, 2005).

Although primordial sentiments were conceived as sedimentation in a long term fabrication of non-democratic modern Indonesia, local intellectuals did not have the opportunity to cultivate the idea of democracy. Under the state patronages, research on primordial ties had strengthened the essentialist view of primordial sentiments and constructed the politicization of cultural identities. They tended to undermine the existence of civil society rather than take part in fertilizing the growth of civil society. They had the inclination to keep distance from so called "public intellectuals", as proposed by Manheim (1952), Mills (1959), Friedrichs (1972) and later developed by Burawoy (2004) through the concept of public and critical sociologist.

\section{The Transitional Stage Thesis}

Some authoritative scholars who produced the transitional stage thesis were Clifford Geertz, W.W Rostow and David McCleland, while scholars from Indonesia were Koentjaraningrat, Selo Soemardjan, Soetrisno, and Parsudi Suparlan. The common idea that these scholars shared was concerned with the inevitability of transition stage to achieve modern Indonesia through the hands of Western European- and North American countries.

The arguments ran as follow: The need of Indonesia and most of the countries in Asia, Africa, and Latin America for development. It was only through development, that they would be able to modernize. Modernization itself was justified from diverse scientific standpoints. From the perspective of international relations the process was crucial in blocking the spread of communism (during the Cold War). (Note 2) Adopting the ideas of influential modern theories, development and modernization were also scientifically justified: societies had the ability to increase in size and complexity. In other words, epistemologically the society of the periphery comes to be understood as an imperfect extension of metropolitan modernity (Connell, 2011)

Within this context, to modernize Indonesia and the non Western world at large, attempts of minimizing tensions had to be done. And yet, they were unavoidable. Transition was considered as inevitable for the making of a better future, namely, modern society. This stage was painful, and yet it had to be passed. Often this process resulted on the creation of human cost both in terms of physical and meaning as experienced by majorities of Third world countries (Berger, 1974) including Indonesia (Sutopo, 2012a). The occurrence was due to, amongst others, the legacy of the past, which had not been completely dissolved or transformed. Consequently, patrimonial ties, for example, affected such modern political institutions as political party and government, which were non-existent in the modern West (Geertz, 1960).

As proponents of diffusionism had claimed, the better future itself did not necessarily duplicate Western capitalism. Western capitalism rather provided the image of a "road map", a normal way of life. Here, traditions and cultural legacy at large could be (and had to be) managed in order to make them supportive to development and modernization (i.e., order and progress) - it resulted in the creation of kebudayaan nasional (national culture) which constructed as the ideal form for the kebudayaan daerah/local culture (Hadiz \& Dhakidae, 2005). And it was the moral role of the state to manage culture as well as the economy and political life.

In managing the transitional stage, social and cultural engineering had to be done on different levels -simultaneously. Population growth had to be lowered. People's mindset had to be adjusted to such an extent that they were supportive of the development. At least, they were not on the path of development. In contrast with the vision of the thesis, its practice had reproduced the abnormality of Indonesia. The discourse of "transition stage" justified economic growth based on low salary, demolition of squatters, conversion of padi field into industrial estate, and other measurements to marginalize the poor. Those were fabricated as "cost for a better future" (Samuel, 2010). The pay back would be through "trickle down" effects. (Note 3) Unfortunately, the abnormality did not disappear along with economic growth. The State had reinvented Indonesian history in such a way as if development began only with the rise of the New Order to power. Sustainable high economic growth did not automatically bring about implementation of Human Rights and democratization. The growth only reproduced (authoritarian) regime maintenance. Authoritarian, homogenization, Javanization were fabricated as functional for "order and progress" (Feith, 1980). Further, Heryanto (2006) explained: "Stages of development" implied the normalcy of maintaining the strong state format by use of coercive force and state terrorism. The state had control over "the speed" and the authority to define how fast was fast. On the other hand, civil society organizations were mobilized under State patronage.

Within this context, scientific knowledge was viewed as, in Comte's term, "adequate knowledge", which was 
required for development and modernization. In practice, good researchers were the ones who were able to supply data - scientific methodology was the only accountable mechanism for acquiring objective data (object oriented knowledge) (MacDougall, 1986). Development and modernization tended to be conceived as technical matters, namely, government strategy. As Shin (1989) had claimed:

From such observations of the developmentalists, it will be safe to say they are almost united in their view on the state-society relationship of the New Order: state dominance.

He added that along with the usage of scientific knowledge for prescriptive measurement, the knowledge had developed a favor for pragmatic modernizing elite and delegitimized the irrational, nationalistic elites and their nation building project. In other words, following Habermas (1971) this scientific knowledge implicitly has a hidden agenda especially its technical interest.

Impact of the transitional stage thesis had been prevalent. Up until now, globalization - a significant factor in restructuring the state - had made the Indonesian academic community difficult to comprehend. Globalization was perceived only as an "external factor", a context of Indonesian social sciences. Furthermore, there was an inclination to associate globalization with Western European and North American social sciences.

\section{The Historical-Structural Thesis}

Amongst influential proponents of the historical-structural thesis were Richard Robinson, Vedi Hadiz, and Yoon Hwan Shin. They used Marxist and Neo-Marxist proposition, as interpreted by Hamza Alavi, Nicolas Poulantzas, and Emmanuel Wallerstein, to fabricate the image of Indonesia. Outside university, several critical public intellectuals and Non-government organizations (NGOs) also shared the conception of this thesis. Their analyses were based on such concept as capital formation in creating an image of Indonesia as a peripheral entity in relation to advanced capital.

According to the political economy perspective, capital formation in the Third World was different from the one in the First World. And yet they were interconnected- in exploitative and dominative fashions - into a system (Note 4) -- since colonial times. As such, Indonesian society had inherited the over developed political structure of the colonial master when the latter officially left Indonesia. (Note 5) The Indonesian state was structurally and historically constrained by the legacy. What the state had done was to adopt and modify the legacy. (Note 6) Basic problems within Indonesia remained the same: inequality, periphery, comprador, corruption (Note 7), collusion and nepotism. Within this context, proponents of the thesis disagreed with the idea that the spread of democratization was a globalization of universal values. It was rather to support the political economy interests of capitalism in a different context (Hoogvelt, 2001). Here, according to orthodox political economy, keindonesiaan/Indonesia-ness was only an illusion. (Note 8)

Political economy's standpoint opens up a forum for criticizing the "state qua state" thesis (e.g., Ben Anderson's Indonesia) or the liberal conceptions of Indonesia's connections with the advanced capitalist countries. Unfortunately, the thesis had an a priori perception of the Indonesian State. Their focus on formation of capitalism had developed an inclination to emphasize the role of the Indonesian state as "instrument" of international capitalism in shaping Indonesia according to its interests. The analysis of Indonesia had also created room for analyzing the dynamic of capital. It was assumed that the market, historically, was not completely autonomous vis-à-vis the state. They were interrelated in such a complex way - to defend their interests (Shin, 1989).

By consequence, the historical-structural thesis had limited interests in civil society organizations. The dynamic of civil society organizations (CSOs) and political organizations (Pos) were perceived as dependent on the dynamic of the capital. This had been so due to colonial (and neo-colonial) disruption of internal development of Indonesia - impacts of imperialism.

\section{The Cultural Imperialist Thesis}

Proponents of the cultural imperialist thesis claimed that power relations between Asia and the West did not occur only in terms of political economy. It was also observable in the cultural realm - since colonial times. They problematized the superiority of Western constructs over Asia, by sharing a conviction that such ideologization was socially constructed. In so doing, they refuted such basic idea of universalism and dichotomizing the West and the rest as the other. The cultural imperialism thesis was built by several influential figures, across disciplinary boundaries, such as Edward Said, Homi Bhaba and Gayatri Spivak. They shared the poststructuralist conceptions of perceiving social life. On Indonesia, several authoritative researchers had done studies on the impact of Western cultural constructs, such as, "Negara Integralistik" (Integralistic State), State terrorism (Heryanto, 2006) and Rethinking Indonesia (Philpott, 2000) 
According to Hoogvelt (2001) the cultural imperialist thesis is belong to the postcolonial thesis. She argues the term 'postcolonial' was a member of a family of 'post' literature, of which 'postmodernism' was the all-embracing generic term. (Note 9) And, as was the case with all this 'post' literature, the word 'post' pulled us into a semantic trap. It expressed an epistemological break with the all-encompassing totality of Western thought and scientific tradition while also signaling the sequence of an epoch. The problem, however, is that those who make the epistemological break reject the 'foundationalism'; and the 'essentialism' that underpins the historical analysis by which the epoch of succession is diagnosed. Needless to say, this has led to largely fruitless debates between the two camps." (Hoogvelt, 2001)

Generally speaking, the thesis focused on Indonesian-ness as the other, that is, Indonesia and Indonesian-ness had been constructed by Western European and North American scholarship rather than by Indonesians themselves. Contemporary post-colonial researchers, broadly speaking, used problematization of this approach to study the dynamics of imperialist cultural formations in former colonies. Based on the maxim that societies had their past as well as future, it was believed that imperialism did not automatically vanish along with the end of direct colonialism. Not only did its existence linger in specific practices, but also in the general cultural sphere. According to Said (1994), it existed in social practices, theoretical constructions, and attitudes of a dominating metropolitan center ruling a distant territory. (Note 10) The self evidence of domination itself was maintained to confirm European power from the start of colonialism on an impressive circular logic of binary opposition:

We are dominant because we have the power (industrial, technological, military \& moral) and they don't, because of which they are not dominant; they are inferior, we are superior ... and so on and on (Said, 1994).

Imperialism, then, interconnects with racism and ethnocentrism. Within this context, Indonesia had rigidly been perceived as the other, that is, the contrasting image of the West. The sense of difference had been created and recreated through time. As such, dominant scientific constructs had the tendency to emphasize the importance of setting up cultural boundaries of Indonesia and essential characteristics of Indonesians, and subsequently as a problem to be solved. Indonesians, in this sense, were not viewed as citizens. (Note 11)

Following the era of Independence of Asian countries in the mid 1960s, postcolonial predicament was evident in those countries. Students of societies and history had found themselves stem from a growing awareness of the role of their academic disciplines in the reproduction of patterns of domination (Breckenridge \& Veer, 1993). Furthermore, the postcolonial predicament had two dimensions: (a) The colonial period has given us both the evidence and the theories that select and connect them; (b) Decolonization does not entail immediate escape from colonial discourse (Breckenridge \& Veer, 1993). This was also evident on Indonesian scholarship by Indonesian intellectuals as explained by Alatas (1993) and Alatas (2006) through his idea about the sociology of the fool. Later Houtoundji in Connell (2011) analyzed based on the context of Africa and proposed what he called extroversion. This 'internal orientalism' was by far the most problematic feature of the Post-colonial Predicament (Brickenridge \& Veer, 1993). And unfortunately it remained uncovered up until now. Most academics remain faithful to the idea of the universalism of their scientific disciplines and the doctrine of objectivity of science.

Broadly speaking, the (cultural) other criticized the colonial discourse on universalism and monolithic character of culture. Philpott had made a detailed observation on the Indonesian state, he claimed that "Discourses of American Orientalism constitute their objects within a range of epistemic formations such as development [...], geo-politics [...] and more recently, the political economy of culture (Philpott, 2000). He continued that "if there is a specifically American Orientalism that contributes to the maintenance of American hegemony in the post-WWII period, then 'meaning' and 'context' are inextricably bound" (Philpott, 2000).

\section{Reflection as an Indonesian Sociologist: Changing Context, Knowledge Production and Power Relations}

Reflexively, both of us realized that as Indonesian sociologists who produced and reproduced knowledge, we are related to historical, socio-cultural and political context (Mannheim, 1952), the feel of the game in the academic field (Bourdieu, 1984), relations of power (Foucault, 1980) as well as inequality of global knowledge production between Metropole/Global North and Periphery/Global South (Connell, 2007). Four sociological concepts of modern Indonesia that we examined gave an example of the complex relation of knowledge, context, and power both in national and global scope of analysis.

The first author who developed his career as a sociologist in the era of New Order found that the state control was almost total in every aspect of life, including education. The characteristics of New Order Regimes which were based on military approaches, terror (including physical-psychological violence) and censorship of information created almost no freedom in producing knowledge. Aside from this some of the colleagues of the first author at that time were working both as bureaucrats and academicians (Samuel, 2001) This ambiguity of 
positions created bias of interest in their knowledge production, the majority of them produced knowledge that supported the agenda of development and modernization from New Order regimes (Hadiz \& Dhakidae, 2005).

Moving on to the analysis of the academic field, especially in universities, the total control of the state also constituted the doxa, habitus as well as the feel of the game in the academic field (Bourdieu,1984). Several explanations can be described here; the state as the patron of university including as a source of funding for research directing the angle of knowledge that was produce through research activities (Nugroho, 2005). Knowledge that was produced from research was not allowed to attack the state agenda, on the contrary it had to serve the development and modernization agenda. The harmonious relations with the state agenda also allowed sociologists to develop their professional career whether inside or outside university, this became a cultural and social capital for sociologists and as explained by Bourdieu and Wacquant (1992) it could easily be converted into another capital to gain a more attractive position in the academic field. These types of knowledge that served the state agenda was produced by professional and policy sociologists (Burawoy, 2004) - while public and critical sociologists were just minorities in the context of the New Order in Indonesia (Achwan \& Gardono, 2005).

Further in terms of curricula, the state also decided some of the sociology subjects in the education curriculumas a result the "sociology of development" subject was created which consisted of modernization theory (Nugroho, 2005) and also the "social systems of Indonesia" subject which consisted of a functionalist approach to understanding Indonesia as a harmonious family. In the area of sociological theory, dominantly classical and modern sociological theory became the main subjects.

Globally, as a result of inequality between Metropole and Periphery there were dependent relations between sociologists in Indonesia and their colleagues from America, this extended to theory, methodology, academic media (journals, books) as well as obtaining funding from Metropole countries. Houtondji in Connell (2011) described this phenomenon as extroversion, some of his thesis including: 1) Dependence on imported apparatus, 2) Dependence on journals, libraries, publishing house and dissemination of research findings, 3) Theoretical extroversion. As explained in our argument before, inequality of relations created non reflexive production of knowledge among Indonesian sociologists. They were unaware of the implicit interest (modernization goals) in the knowledge that they consumed and produced. As a result, sociologists became solely the knowledge translators of their colleagues from Metropole, Alatas (2010) described this phenomenon as a captive mind. Further, Indonesian sociologists purely served the role of data collectors about phenomena in Indonesia for their colleagues from Metropole, they seldom created their own theory based on the social context of Indonesia as Connell (2007) proposed as southern theory. This “division of labor' reflected the global inequality of knowledge production as explained by Connell (2011):

The process of producing knowledge in the Metropole and the Periphery are differently structured in practice. This follows from global inequalities, the legacy of imperialism, that have constituted the Metropole as the home of theory, or science as such, and the Periphery as either the source of data, or the arena in which metropolitan knowledge is applied.

While the second author who studied and developed his career in the era of reformation experienced several ambiguities in the academic life. The shift from authoritarian regime into relatively more democratic regime resulted in the freedom of speech and knowledge production but on the other hand it also means a shift of power from state to market (Sutopo, 2012a). In other words, Indonesia now is under the regime of neo-liberalism (Note 12) which directed majorities of research agenda to support the agenda of deregulation, liberalization and privatization to create free market goals. As explained by Connell (2013):

Neoliberalism seeks to make existing markets wider and to create new markets where they did not exist before. Neoliberalism pushes towards the universal commodification of services, many public assets have been privatized and have had astonishing success in creating markets for things whose commodification was once almost unimaginable.

There is great tendency for both universities and sociologists to accept funding from Trans/Multinational Corporations and international organization. After becoming the loyal supporter of the state, now there are increasing trends for Indonesian sociologists to become professional consultants for corporations as well as international organization. As a result they produce knowledge in the form of prescriptions and solutions (Achwan \& Gardono, 2010) to support their client agendas, for example as a consultant for the corporate social responsibility program (CSR) and consultant for international development projects. Similar to previous regime, the public and critical sociologist remain in the marginal position.

We also found ambiguities in the curriculum of sociology in Indonesia. We can say that it is more open after the 
reformation era. In terms of sociological theory, several big universities in Indonesia (for example, University of Indonesia \& Gadjah Mada University) already incorporated critical theory, postmodern theory, postcolonial theory and even southern theory in the case of Gadjah Mada University (Sutopo, 2012b). In general, some material in sociology subjects are more oriented to ideas of democracy, participation, freedom, good governanceat the other hand we can also find a tendency to the idea of individual freedom (viewing humans as individuals who free to choose). Despite the openness in the curriculum of sociology, the agenda of the state still relatively exists in several sociology subjects (for example sociology of development, social systems of Indonesia, political systems of Indonesia), and for some universities in Indonesia there is still strong orientation to the agenda of development and modernization. We propose the ambiguity condition of sociology subjects in post-reformation Indonesia as a "chaotic".

\section{Conclusion}

The four sociological concepts of modern Indonesia that we examined showed the linkage between knowledge production and power, as well as its interrelation between the scope of nation state and global scope. Four sociological concepts that were produced in the era of the New Order were not neutral, objective and universal. The mantra of neutrality, objectivity and universality were claims that made to hide the will for power inside the knowledge that had been produced.

Based on our findings, these four sociological concepts of modern Indonesia conceal the interest of the state (New Order regime) to maintain its agenda of development and modernization, with the ideal type of society that became the role model for modern Indonesia implicitly being western or northern society. In this sense, we agree with Connell (2011) that the society of the Periphery comes to be understood as an imperfect extension of Metropolitan modernity, and this hidden assumption justified the implicit concept of order and progress in the knowledge that had been produced. Even though the four sociological concepts that we examined offer different explanation about modern Indonesia and showed that it was not monolithic, all the thesis implicitly hide the same grand narrative - the modernization perspective.

Our spirit in this article is looking back, creating the future. We hope that by exposing the linkage between knowledge and power in the context of New Order Indonesia it will inspire Indonesian sociologists as knowledge producers and consumers to: 1) reflexively examine the relation of knowledge and power that they produce and consume, 2) learn the positive as well as negative lessons from the history of Indonesian sociology and 3) locate the lessons as important sources to create better future of Indonesian sociology.

\section{References}

Achwan, R., \& Sudjatmiko, I. G. (2010). Contesting Mainstream Sociology and Developing Alternative Public Sociologies in Indonesia. In M. Burawoy, M. Chang \& M. F. Shieh (Eds.), Facing Unequal World: Chalenges for Global sociology (pp. 244-265). Taiwan: Institute of sociology at Academia Sinica.

Alatas, S. F. (1993). On the Indigenisation of Academic Discourse. Alternatives, 37-58.

Alatas, S. F. (2010). Diskursus Alternatif dalam Ilmu Sosial Asia: Tanggapan terhadap Eurosentrisme. Jakarta: Mizan Publika.

Alatas, S. H. (1977). The Myth of the Lazy Native. Malaysia: Forest Grove.

Alatas, S. H. (2006). The Autonomous, the Universal and the Future of Sociology. Current Sociology, 54(1), 7-23. http://dx.doi.org/10.1177/0011392106058831

Berger, P. L. (1974). Pyramids of Sacrifice. New York: Penguin Books.

Bourdieu, P. (1984). Homo Academicus. Cambridge: Polity Press.

Bourdieu, P. (1998). Outline of a Theory of Practice. Translated by Richard Nice. Cambridge: Cambridge University Press.

Bourdieu, P., \& Wacquant, L. (1992). An Invitation to Reflexive Sociology. Cambridge : Polity Press.

Breckenridge, C. A., \& Veer, P. V. D. (Eds.) (1993). Orientalism and the Post-colonial Predicament: Perspectives on South Asia. Philadelphia: University of Pennsylvania Press.

Burawoy, M. (2004). Public Sociologies: Contradiction, Dilemmas and Possibilities. Social Forces, 82(4), 1603-1618. http://dx.doi.org/10.1353/sof.2004.0064

Connell, R. (2007). Southern Theory: The Global Dynamics of Knowledge in Social Science. Australia: Allen and Unwin.

Connell, R. (2010). Periphery and Metropole in the History of Sociology. Sociologisk Forksning, 72-86. 
Connell, R. (2011). Confronting Equality: Gender, Knowledge and Global Change. Australia: Allen and Unwin.

Connell, R. (2013). The Neoliberal Cascade and Education: an essay on the market agenda and its consequences. Critical Studies in Education, 54(2), 99-112. http://dx.doi.org/10.1080/17508487.2013.776990

Dhakidae, D. (2003). Cendekiawan dan Kekuasaan dalam Negara Orde Baru (Intelectuals and Power in The New Order State). Jakarta: PT Gramedia.

Feith, H. (1980). Repressive-Developmentalist Regimes in Asia: Old Strengths, New Vulnerabilities. Prisma: the Indonesian Indicator, 19(December), 39-55.

Foucault, M. (1980). Power/Knowledge: Selected Interviews and Other Writings. New York: Pantheon.

Friedrichs, R. (1972). A Sociology of Sociology. New York: Free Press.

Geertz, C. (1960). The Religion of Java. Chicago: The University of Chicago Press.

Geertz, C. (Ed.) (1973). The Interpretation of Cultures. New York: Basic Books.

Habermas, J. (1971). Knowledge and Human Interest. Boston: Beacon Press

Hadiz, V. R. (2005). Dinamika Kekuasaan: Ekonomi Politik Indonesia Pasca Soeharto. Jakarta: LP3ES.

Hadiz, V. R., \& Dhakidae, D. (Eds.) (2005). Social Science and Power in Indonesia. Equinox: Singapore.

Heryanto, A. (2006). State Terrorism \& Political Identity in Indonesia. New York: Routledge

Hoogvelt, A. (2001). Globalization and the Postcolonial World: the New Political Economy of Development. Baltimore: the Johns Hopkins University press.

Laksono, P. M. (2005). Social Science Associations. In V. R. Hadiz \& D. Dhakidae (Eds), Social Science and Power in Indonesia. Singapore: Equinox

MacDougall, J. J. (1986). The Technocratic Model of Modernisation: the Case of Indonesia's New Order. Asian Survey, 16, 1166-1183. http://dx.doi.org/10.2307/2643453

Mannheim, K. (1952). Essays on the Sociology of Knowledge. London: Routledge and Kegan Paul.

Mills, C. W. (1959). The Sociological Imagination. New York: Oxford Press.

Nasikun. (2005). Peran ilmu-ilmu sosial dan humaniora bagi liberalisasi dan humanisasi teknologi. Yogyakarta: Gadjah Mada University.

Nugroho, H. (2005). The Political Economy of Higher Education: The University as an Arena for the Struggle for Power. In V. R. Hadiz \& D. Dhakidae, Social Science and Power in Indonesia. Singapore: Equinox.

Nugroho, H. (2012). Negara, Universitas dan Banalitas Intelektual: Sebuah Refleksi Kritis dari Dalam (State, University and Banality of Intelectuals: an Insider's Reflection). Yogyakarta: Gadjah Mada University.

Philpott, S. (2000). Rethinking Indonesia: Postcolonial Theory, Authoritarianism and Identity. Pallgrave mcmillan

Rochman, G., \& Achwan, R. (2005). Inclusion and Exclusion: NGOs and Critical Social Knowledge. In V. R. Hadiz \& D. Dhakidae (Eds.), Social Science and Power in Indonesia. Singapore: Equinox.

Rossa, J. (2008). Dalih Pembunuhan Massal. Jakarta: Hasta Mitra.

Said, E. W. (1978). Orientalism: Western Conceptions of the Orient. London: Penguin Books

Said, E. W. (1994). Culture and Imperialism. London: Vintage

Samuel, H. (2001). The Development of Sociology in Indonesia: The Production of Knowledge, State Formation and Economic Change. Ph.D thesis Swinburne University of Technology.

Samuel, H. (2010). Universitas, Negara dan Masyarakat Indonesia: Implementasi Paradigma Modernisasi dalam Era Orde baru. Humaniora, 31-42.

Shin, Y. H. (1989). Demistifying the Capitalist State. PhD thesis, Yale University.

Simpson, B. (2008). Economist with Guns. California: Stanford.

Soemardjan, S., \& Soemardi, S. (1964). Setangkai Bunga Sosiologi. Jakarta: Jajasan Badan Penerbit Fakultas Ekonomi Universitas Indonesia.

Sutopo, O. R. (2012a). Biaya-biaya Manusia Dalam Era Neoliberal: Sebuah Imperatif (Human Costs in The Neoliberal Era: an Imperative). Jurnal Pemikiran Sosiologi, 30-43. 
Sutopo, O. R. (2012b). Is There Southern Theory in Indonesian Sociology? Paper presented at The 11th APSA Sociological Conference, Ateneo de Manila University Philipines 22-24 October.

Wertheim, W. F. (1969). Indonesian Society in Transition: a Study of Social Change. The Hague: W. Van Hoeve

\section{Notes}

Note 1. In terms of global knowledge production especially between Metropole/Global North and Periphery/Global South despite this relatively open academic atmosphere, southern theory (Connell, 2007) has not emerged in majority of sociological theory teaching and further based on Indonesian experiences as explored by Sutopo (2012b).

Note 2. The Cold War era is, roughly speaking, an era between the $2^{\text {nd }}$ World War and the collapse of the Soviet Union.

Note 3. According to Hoogvelt (2001, p. 227), "The record of social progress as measured by declining income inequality and poverty levels continued to be a matter of interpretation and dispute."

Note 4. Generally speaking, historical structural theories do not view Indonesia as a powerless victim of international capitalism. Shin (1989) has shown how capital formation in New Order Indonesia has been incomplete - due to, amongst others, the interference and domination of the political power. Similar views can also be found in Hadiz's and Robinson's works.

Note 5. There was a tendency to emphasize the relative autonomy of the Indonesian state vis-à-vis the capital foreign and local alike. The state has room for alternatives and a degree of freedom in policy making.

Note 6. Quite interestingly, an overdeveloped state with equally exploitative and oppressive legal, economic and political institutions culminated in the New Order. (Shin, 1989, p. 45)

Note 7. Corruption was primarily due to the control of the military and bureaucrats in particular over economic resources. On the other hand, societal control over the state was practicaly absent.

Note 8. The exclusion of cultural analysis was not complete. According to Hoogvelt (2001), for example, political economy has open space for excursions into what she calls "comparative political economy".

Note 9. We disagree with Hoogvelt (2001) that the postcolonial studies were a part of postmodernism. Had she consulted Said, Spivak, Bhaba, and other researchers of postcolonial studies, she would have realized the bias of her proposition.

Note 10. Another meaning attached to "post-colonial" has been associated with an era. In so far as post-colonial researchers were concerned, this was misleading.

Note 11. It was in relation with the idea of Western's perspective of the East, that the term "Orientalism" had been most popular. It was, amongst others, Edward Said who had used the term widely. Unfortunately he did not have a single compact conception of the term. (1) "Orientalism is a style of thought based upon an ontological and epistemological distinction made between 'the Orient' and (most of the time) 'the Occident". (Said, 1978, p. 2) (2) "Orientalism is the generic term that I have been employing to describe the Western approach to the Orient; Orientalism is the discipline by which the Orient was (and is) approached systematically, as a topic of learning, discovery, and practice. But in addition I have been using the word to designate that collection of dreams, images, and vocabularies available to anyone who has tried to talk about what lies east of that dividing line. (Said, 1978, p. 73) (3) "Orientalism can be discussed and analyzed as the corporate institution for dealing with the Orient -- dealing with it $\mathrm{b}$ making statements about it, authorizing views of it, describing it, by teaching it, settling it, ruling over it: in short, Orientalism as a Western style for dominating, restructuring, and having authority over the Orient." (Said, 1978, p. 3)

Note 12. According to Nasikun (2005) the main global neoliberal actors he called "The unholy trinity" consist of the World Bank/International Monetary Fund (IMF), the World Trade Organization (WTO) and Trans/Multinational Corporations.

\section{Copyrights}

Copyright for this article is retained by the author(s), with first publication rights granted to the journal.

This is an open-access article distributed under the terms and conditions of the Creative Commons Attribution license (http://creativecommons.org/licenses/by/3.0/). 